\title{
KAJIAN : KARAKTERISASI SENYAWA AKTIF ASAM KLOROGENAT DALAM KOPI ROBUSTA SEBAGAI ANTIOKSIDAN
}

\author{
Review : Characterization of active compounds in Robusta coffee as antioxidants
}

\author{
Husniati Husniati, Mentari Yunika Sari, dan Amelia Sari \\ Balai Riset dan Standardisasi Industri Bandar Lampung, Jl. By Pass Soekarno-Hatta Km. 1 Rajabasa, \\ Bandar Lampung-35144, Indonesia \\ e-mail: husniati@kemenperin.go.id
}

\begin{abstract}
Abstrak
Kopi dikenal sebagai sumber tanaman yang mengandung senyawa fenolik natural yang bertanggung jawab terhadap aktivitas antioksidan. Umumnya senyawa fenolik yang terkandung dalam tanaman memiliki fungsi penting untuk bahan-bahan aditif yang biasa ditambahkan ke dalam produk makanan, farmasi dan obat sehingga produk tersebut memiliki sifat-sifat antioksidan dan memberi efek salah satunya memperpanjang umur simpan serta sifat-sifat fungsional lainnya. Penelitian ini akan membahas bagaimana peran senyawa fenolik asam klorogenat dalam kopi sebagai antioksidan dan bagaimana penentuan analisis antioksidannya menggunakan metode DPPH (2,2'-diphenyl-1-picrylhydrayl).
\end{abstract}

Kata kunci:antioksidan, DPPH, kopi, Robusta, senyawa fenolik.

\begin{abstract}
Coffee is known as a plant source that contains natural phenolic compounds which are responsible for antioxidant activity. Generally, phenolic compounds contained in plants have an important function for additives commonly added to food, pharmaceutical and medicinal products so that the product have antioxidant properties and give the effect of one of them extending shelf life and other functional properties. This study will discuss the role of phenolic compounds in coffee as an antioxidant and how the determination of antioxidant analysis using the DPPH $(2,2$ 'diphenyl-1-picrylhydrazyl) method.
\end{abstract}

Keywords:antioxidant,coffee, DPPH,Robusta, phenolic compounds.

\section{PENDAHULUAN}

Indonesia tercatat sebagai produsen dan eksportir kopi terbesar kedua di Negara ASEAN setelah Vietnam namun juga disebut sebagai importir kopi keempat ASEAN setelah Filipina, Malaysia, dan Thailand. Berdasarkan data Ditjen Perkebunan tahun 2015, produksi kopi di Indonesia pada tahun 2019 mencapai 729.074 ton, mengalami peningkatan dari tahun 2015 yang sebelumnya sebesar 639.412 ton (Ditjend Perkebunan, 2020). Produksi kopi Indonesia di ekspor ke Amerika Serikat sebesar 52.10 ribu ton $(18,61 \%$ dari total volume ekspor), ke Malaysia sebesar 38,80 ribu ton $(13,86 \%$ dari total volume ekspor), ke Jepang sebesar 30,37 ribu ton $(10,85 \%$ dari total volume ekspor), ke Mesir sebesar 29,31 ribu ton $(10,47 \%$ dari total volume ekspor) (BPS, 2018). Proyeksi produksi kopi tahun 2020 digambarkan memberi kecenderungan meningkat hingga 7,6 \% (Triyanti, 2016).

Kopi diminati sebagai minuman oleh banyak kalangan anak muda dan orang tua di mana pun berada karena aromanya. Aroma kopi dibentuk oleh senyawa volatil yang terkandung dalam kopi.
Minuman kopi berkolaborasi dengan minuman kesehatan (Farah dan dePaula Lima, 2019).

Di dalam minuman kopi terkandung banyak senyawa aktif yang termasuk dalam kelompok senyawa fenolik. Senyawa fenolik dan juga senyawa flavonoid telah dilaporkan memiliki efek positif pada kesehatan dan terapi medis (Venugopal dan Liu, 2012; Panche et al., 2016). Senyawa fenolik dilaporkan sebagai sumber antioksidan (Rice-Evans et al., 1996). Sementara itu, Davalos et al. (2005) menyampaikan bukti epidemiologis yang mengaitkan pola kesehatan masyarakat dalam penanganan penyakit bahwa terdapat korelasi terbalik antara asupan makanan senyawa fenolik dengan penurunan penyakit kronis tertentu. Kopi yang dikonsumsi secara teratur memiliki efek positif antara lain respon psikoaktif (kewaspadaan, mood swings), neurologis (hiperaktif dini, penyakit Alzheimer dan Parkinson), gangguan metabolisme (diabetes, batu empedu, sirosis hati), dan fungsi kelenjar kelamin dan hati (Do 'rea, JG dan da Costa, 2005).

Mulato et al. (2001) melaporkan bahwa kopi mengandung berbagai jenis senyawa, antara lain 
kafein, asam klorogenat, trigonelin, karbohidrat, lemak, asam amino, asam organik, aroma volatil, dan mineral. Sedangkan menurut Mursu et al. (2005), kopi juga mengandung beberapa komponen fenolik selain tokoferol yang menunjukkan kapasitas antioksidan seperti asam klorogenat, asam kafeat, asam ferulat, dan asam p-kumarat yang terdapat dalam bentuk bebas. Asam klorogenat menunjukkan sifat antioksidan yang kuat terhadap penyakit degeneratif terkait usia, membatasi oksidasi lipid LDL/low-density lipoprotein dan menghilangkan spesies reaktif beracun (Stalmach et al., 2006; Belay dan Gholap, 2009).

Sumber antioksidan dari senyawa polifenol dijelaskan secara kimiawi bahwa polifenol memiliki ketersediaan hidrogen yang didonorkan untuk menangkal kerusakan akibat radikal bebas sehingga dalam konsentrasi rendah dapat menghambat, menangkal, atau mencegah reaksi oksidasi. Radikal bebas terbentuk secara alami dari proses pernapasan yang menghasilkan energi tetapi juga menghasilkan oksigen reaktif sebagai produk sampingan yang disebut ROS (spesi oksigen reaktif) [Pizzino et al., 2017]. Antioksidan alami dari senyawa fenolik dapat melindungi lipid, protein dan DNA terhadap radikal oksigen dan nitrogen (ROS dan RNS) (Willett, 1994).

Radikal bebas juga dihasilkan dari proses pengolahan makanan berkadar lemak tinggi pada suhu tinggi. Peristiwa oksidasi terjadi pada lemak karena ada perubahan mulai dari penyiapan bahan makanan yang terpapar panas, cahaya, atau radiasi pengion hingga mempengaruhi kualitas gizi, warna, tekstur, dan ketengikan (Shahidi dan Wanasundara, 1992). Terbentuknya ketengikan pada lemak sebagai indikasi munculnya radikal bebas. Zat gizi dalam pangan tidak hanya lemak tetapi terdapat juga protein dan senyawa fenolik yang berperan dalam menghambat oksidasi zat gizi yang ada pada produk pangan sehingga hal ini berdampak pada memperpanjang umur simpan produk. Fungsi antioksidan dalam makanan mengontrol ketengikan, menghambat produk oksidasi, mempertahankan kualitas nutrisi, berpengaruh pada peningkatan umur simpan (Yashin et al., (2017), serta digunakan sebagai pengawet makanan (Lourenco et al., 2019). Memperpanjang umur simpan produk juga dibatasi oleh lama penyimpanan. Penyimpanan biji kopi organik selama 12 bulan dapat menurunkan kandungan polifenol dan mempengaruhi bioaktivitas asam klorogenat yang mulai/telah terdegradasi (Krol, et al., 2019).

Dalam Industri pengolahan selain pangan seperti farmasi, antioksidan menjadi bahan tambahan sebagai solusi mencegah oksidasi dan menghasilkan produk bertambah kuat dalam rasa, aroma, dan warna. Saat ini permintaan antioksidan sintetis seperti BHT (butil hidroksi toluen) semakin terbatas karena memberikan efek samping dan tidak aman bagi kesehatan. Permintaan dari bahan antioksidan sintetis telah beralih memanfaatkan antioksidan alami yang berasal dari bahan nabati yang mengandung tanaman fenol yang lebih sehat dan aman (Kebede dan Admassu, 2019).

Kelompok utama senyawa fenolik adalah asam hidroksi sinamat yang banyak ditemukan hampir setiap tanaman. Asam hidroksi sinamat adalah asam kafeat yang membentuk esterifikasi dengan asam quinat yang menghasilkan asam klorogenat (Hall et al., 2015; Hounsome et al., 2008; Rice-Evan et al., 1996). Senyawa antioksidan ini bekerja sebagai inhibitor yang menghambat reaksi oksidansi berkelanjutan dengan cara bereaksi dengan oksigen radikal bebas menghasilkan radikal bebas tak reaktif dan stabil.

Struktur kimia asam klorogenat terdiri dari ester asam kafeinat dan asam quinat yang ditunjukkan pada Gambar 1.<smiles>O=C(O)/C=C/c1ccc(O)c(O)c1</smiles>

a. $\quad$ asam kafeat (Hall et al., 2015)<smiles>O=C(O)[C@]1(O)C[C@@H](O)[C@H](O)[C@H](O)C1</smiles>

b. Asam quinat (Wikipedia, 2008)<smiles>O=C(/C=C/c1ccc(O)c(O)c1)O[C@@H]1C[C@](O)(C(=O)O)C[C@H](O)[C@H]1O</smiles>

c. Asam klorogenat (Hall et al., 2015)

Gambar 1. Struktur kimia asam klorogenat (c) yang dibentuk dari asam kafeat (a) dan asam quinat (b)

Untuk mengetahui peran senyawa fenolik dalam kopi yang berfungsi sebagai antioksidan maka kajian ini akan membahas komponen bioaktif dari asam klorogenat serta penentuan analisis antioksidan menggunakan metode DPPH. 


\section{ASAM KLOROGENAT}

Asam klorogenat banyak ditemukan pada kopi (Pathak et.al., 2013). Dalam $200 \mathrm{~mL}$ minuman kopi instan terkandung 50-150 mg asam klorogenat (Clifford, 2000). Publikasi Scalbert and Williamson (2000) menunjukkan bahwa sumber utama dalam kopi adalah polifenol, selain itu polifenol juga terdapat pada teh, coklat, dan buah-buahan, sehingga menjadi dasar perhatian konsumen untuk memanfaatkannya dalam industri makanan. Ada dua alasan penting mengkonsumsi senyawa polifenol yaitu memberi manfaat pencegahan penyakit diantaranya kanker, stroke, jantung koroner, serta alasan lainnya adalah sebagai agen pereduksi seperti Vitamin C, Vitamin E, dan karetonoid. Asam klorogenat diketahui memiliki antioksidan serupa dengan asam askorbat dan lebih tinggi dari BHT (antioksidan sintetis) [Nakatani et al., 2000]. Diversifikasi polifenol pada struktur kimia membuat perbedaan dalam aktivitas antioksidan. Struktur kimia polifenol mempengaruhi sifat biologinya yaitu bioavailability, aktivitas antioksidan, interaksi spesifik sel reseptor dengan enzim dan lain-lain.

Asam klorogenat dalam biji kopi hijau jumlahnya berkesar antara 7-14,4 \%. Jumlah dominan terdapat pada kopi jenis Robusta (Caffea canephora) sementara pada kopi Arabica (Caffea arabica) mengandung asam klorogenat 4-8,4\% (Farah dan Donangelo, 2006; Cifford et al., 2006). Sub kelompok utama dari asam klorogenat isomerik dalam jumlah mikro adalah asam caffeoquinoic (CQA), asam feruloyloquinic (FQA), asam dicfeoylquinic (di-CQA), dan asam p-cumaroylquinic (p-CQA) (Liang dan Kitts, 2016). Menurut Farah (2006) dan Matei et.al. (2012), asam klorogenat pada biji kopi terdiri atas 9 isomer utama diantaranya 3 isomer CQA (3-, 4-, dan 5-CQA), 3 isomer di-CQA (3,4-, 3, 5-, dan 4,5-di-CQAs), dan 3 isomer FQA (3-, 4-, dan 5-FQAs).

$\begin{array}{ccrr}\text { Asam } & \begin{array}{c}\text { klorogenat } \\ \text { metabolit }\end{array} & \begin{array}{r}\text { diproduksi } \\ \text { sekunder. }\end{array} & \begin{aligned} \text { sebagai } \\ \text { Berdasarkan }\end{aligned} \\ \text { fungsi }\end{array}$ pembentukan metabolit sekunder dari kelompok senyawa fenolik ini sebagai adaptasi tanaman terhadap kondisi stres dari tanaman tersebut. Montavon et al., (2003) melaporkan bahwa kandungan asam klorogenat sebelum mencapai kematangan biji kopi ada pada posisi minimum/rendah, karena biji kopi ini belum memiliki kepekaan terhadap reaksi oksidasi yang berdampak pada penurunan kandungan asam klorogenat termasuk kandungan dari kelompok isomer asam klorogenat lainnya. Sementara kematangan biji makin bertambah muncul sensitivitas terhadap reaksi oksidasi, kematangan biji juga diikuti oleh pembentukan metabolit sekunder sebagai bentuk pertahanan terhadap lingkungan, sehingga biji kopi yang matang memiliki kandungan asam klorogenat yang lebih tinggi.
Kandungan asam klorogenat yang ada pada green bean/biji kopi hijau berbeda dari kopi yang telah disanggrai/roasting. Proses pemanasan terus menerus dari kopi seduh secara tradisional memberikan penurunan jumlah total polifenol. Pemanasan terus menerus memberi dampak degradasi polifenol yang ada dan pembentukan produk yang kurang stabil dan mudah menguap (Asfaw dan Tefera, 2020). Kopi hijau yang tidak disanggrai memberikan kandungan asam klorogenat yang lebih maksimal dan bermanfaat sebagai antioksidan dan aktivitas penangkal radikal. Proses roasting memberi efek hidrolisis parsial terhadap asam klorogenat menghasilkan asam kuinat dan asam sinamat yang selanjutnya mengalami dekarboksilasi menjadi fenol-fenol sederhana dengan berat molekul rendah (Clifford, 2000). Aziz et al., (2009) melaporkan asam klorogenat pada kopi sangrai sebanyak 4,5\%. Selama penyangraian sebagian besar asam klorogenat menjadi asam kafeat dan asam kuinat. Farah dkk. (2005) menyatakan bahwa pengolahan kopi dengan cara disangrai akan meningkatkan kadar asam lakton klorogenat karena semakin banyak prekursor yang terkandung dalam kopi, yaitu asam klorogenat. Kopi yang diolah dengan cara dipanaskan atau disangrai akan meningkatkan tingkat kepahitan kopi karena proses tersebut dapat menimbulkan reaksi millard.

Potensi asam klorogenat telah dimanfatkan untuk beberapa kegunaan diantaranya memiliki aktivitas antioksidan terhadap proteksi hati, hipoglikemia, dan antivirus. Manfaat lainnya dari asam klorogenat dapat memperbaiki penyakit kulit kering (Fukagawa et al., 2017). Aktivitas antioksidan yang terkandung dalam senyawa ini memberikan perlindungan terhadap patogen invasif yang masuk ke dalam tubuh. Aktivitas antioksidan yang terkandung dalam senyawa ini berperan dalam meningkatkan pertahanan terhadap serangan patogen yang masuk ke dalam tubuh. Selain gugus utama yang terdiri dari asam klorogenat, terdapat beberapa gugus minor yang terdiri dari asam caffeoylquinic, asam dicheninoylquinic, asam feruloyquinic, asam p-comaroylquinic, dan ketiga isomernya (Farah dan Donangelo, 2006).

\section{PENENTUAN AKTIVITAS ANTIOKSIDAN SECARA DPPH}

Antioksidan adalah senyawa donor elektron atau reduktor. Senyawa ini mampu menonaktifkan perkembangan reaksi oksidasi, dengan cara mencegah pembentukan radikal. Antioksidan juga dapat didefinisikan sebagai senyawa yang jika dalam konsentrasi rendah, terdapat substrat yang dapat teroksidasi, dapat menunda atau menghambat oksidasi senyawa tersebut (Sunardi, 2007). Metode penentuan antioksidan menggunakan DPPH (2,2difenil-1-pikrilhidrazil) tergolong metode uji yang murah, mudah dan sederhana untuk skrining 
senyawa antioksidan pada sampel padatan dan cair (Prakash et al., 2001; Molyneux, 2004; Rija'i et al., 2019).

Sampel yang mengandung asam fenolik mempunyai aktivitas penangkal radikal ditentukan oleh jumlah hidroksi yang terikat pada cincin aromatik dari benzoil atau dari molekul asam sinamat. Gugus metoksi yang terikat pada posisi 3 dan 5 cincin aromatik dapat meningkatkan aktivitas penangkal radikal untuk senyawa asam fenolik (Nenadis et al., 2003). Potensi antioksidan dari senyawa fenolik berkaitan dengan delokalisasi elektron yang terjadi pada struktur inti aromatik dari asam fenolnya. Ketika senyawa fenolik ini bereaksi dengan radikal bebas membentuk radikal bebas yang baru yang distabilkan oleh adanya efek resonansi dari gugus aromatiknya (Cuvelier et al., 1992; Ozarowski et al., 2019).

Mekanisme reaksi penangkalan radikal ditunjukkan pada Gambar 2 berikut. Gugus kromofor dan auksokrom pada radikal bebas DPPH memberikan absorbansi maksimum pada Panjang gelombang $517 \mathrm{~nm}$. Reaksi penangkapan radikal DPPH oleh antioksidan (Prakash et al., 2001 ) dapat dijelaskan melalui perubahan warna yang terjadi. Warna DPPH pada awalnya ungu berubah menjadi kuning. Perubahan warna kuning diberikan dari gugus pikril yang masih ada seiring denganpenambahan elektron tunggal dari antioksidan kepada radikal DPPH (Molyneux, 2004). Hasil dekolorasi DPPH tereduksi secara stokiometri setara dengan jumlah elektron yang tertangkap molekul reduktannya (Dehpouret al., 2009).

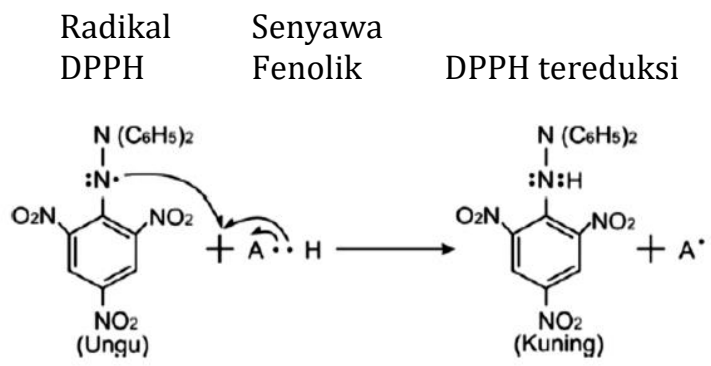

Gambar 2. Mekanisme reaksi identifikasi perubahan warna dari penggunaan DPPH

Asam klorogenat dapat menangkal radikal yang dihasilkan adanya hidroksil $(\bullet \mathrm{OH})$, superoksida $\left(\bullet \mathrm{O2}^{-}\right)$, dan 2,2 diphenyl-1picrylhydrazyl (DPPH •) tergantung dosis/konsentrasinya dengan mekanisme yang mungkin melalui reaksi transfer atom hidrogen di mana radikal bebas memisahkan atom hidrogen dari asam klorogenat atau pembentukan radikal bebas asam klorogenat menjadi radikal intermediet (Nabavi et al., 2017). Cha et al., (2014) mempublikasi hasil risetnya bahwa pada konsentrasi berkisar antara 5-80 $\mu \mathrm{M}$ asam klorogenat mempunyai aktivitas penangkal DPPH atau dengan kata lain asam klorogenat tidak bersifat sitotoksik pada konsentrasi hingga $80 \mu \mathrm{M}$ dengan ditemukan viabilitas sel hingga 100\%. Xu et al., (2012) melaporkan bahwa aktivitas antioksidan sebagai nilai EC 50 aktivitas penangkal radikal DPPH dari asam klorogenat dari isomer 5-CQA $(13.8 \pm 1.3$ $\mu \mathrm{g} / \mathrm{mL}$ ) mempunyai aktivitas lebih rendah dibandingkan BHT/antioksidan sintetis $\quad(39,62$ $\mu \mathrm{g} / \mathrm{mL})$.

\section{KESIMPULAN}

Kajian ekstrak dari kopi diperoleh kandungan senyawa aktif yang tergolong dalam kelompok polifenol seperti asam klorogenat. Biji hijau Robusta mengandung asam klorogenat sebanyak 4-8,4 \% yang diperoleh melalui ekstraksi dengan pelarut yang sesuai. Struktur molekulnya terbangun oleh kerangka dasar fenilpropanoid sebagai cincin aromatiknya. Penangkapan radikal bebas dari DPPH atau elektron tak berpasangan dari DPPH menangkap atom hidrogen dari asam klorogenat dari kopi, memberikan perubahan warna pada 517 nm UV Vis. Perubahan ini memberi angka EC50 (13.8 $\pm 1.3 \mu \mathrm{g} / \mathrm{mL})$ lebih rendah dari BHT $(39,62 \mu \mathrm{g} / \mathrm{mL})$ dan menandai bahwa asam klorogenat adalah antioksidan yang berfungsi sebagai penangkal elektron bebas dari DPPH.

\section{UCAPAN TERIMA KASIH}

Review ini sebagai bagian dari penelitian Litbang Prioritas Nasional berjudul topik Pengembangan Asam Klorogenat Berbasis Kopi Lampung Sebagai Bahan Baku Sediaan Farmasi Substitusi ImportTahun anggaran 2019.

Ucapan terima kasih disampaikan penulis kepada Badan Penelitian dan Pengembangan Industri Kementerian Perindustrian atas pendanaan kegiatan litbang Tahun Anggaran 2019. Ucapan terima kasih juga disampaikan kepada Kepala Satker Baristand Industri dan Pejabat Struktural selama kegiatan litbang dengan memfasilitasi sarana dan prasarana serta monitoring kegiatan. Ucapan terima kasih juga disampaikan kepada semua tim pokja yang telah bekerjasama.

\section{CONTRIBUTORSHIP}

Kontributor utama : Husniati, Kributor anggota : Mentari Yunika Sari, dan Amelia Sari. 


\section{DAFTAR PUSTAKA}

Aziz, T., Ratih C., Asima F. (2009). Pengaruh Pelarut Heksana dan Etanol, Volume Pelarut dan Waktu Ekstraksi Terhadap Hasil Ekstraksi Minyak Kopi. Jurnal Teknik Kimia. 1(16),1-4.

BPS. (2018). Statistik Kopi Indonesia-Indoensian Coffee Statistic. 2018. Katalog 5504006. Jakarta. $99 \mathrm{hlm}$.

Cha, J. W., Piao, M. J., Kim, K. C., Yao, C. W., Zheng, J., Kim, S. M., Hyun, C. L., Ahn, Y. S., and Hyun, J. W. (2014). The Polyphenol Chlorogenic Acid Attenuates UVB-mediated Oxidative Stress in Human HaCaT Keratinocytes. Biomolecules \& Therapeutics, 22(2), 136-142. Doi : 10.4062/biomolther. 2014.006

Clifford, M. (2000). Review: Chlorogenic acids and other cinnamates-nature, occcrrence, dietary burden, absorption and metabolism. Journal of the Science of Food and Agriculture, 80(7), 1033-1043. doi: 10.1002/(SICI)10970010(20000515)80:7<1033::AID-

JSFA595>3.0.CO;2-T

Clifford, M. N., Knight, S., Surucu, B., and Kuhnert, N. (2006). Characterization by LC-MSnof Four New Classes of Chlorogenic Acids in Green Coffee Beans: Dimethoxycinnamoylquinic Acids, Diferuloylquinic Acids, Caffeoyldimethoxycinnamoylquinic Acids, and Feruloyl-dimethoxycinnamoylquinic Acids. Journal of Agricultural and Food Chemistry, 54(6), 1957-1969. doi:10.1021/jf0601665.

Cuvelier, M.-E., Richard, H., and Berset, C. (1992). Comparison of the Antioxidative Activity of Some Acid-phenols: Structure-Activity Relationship. Bioscience, Biotechnology, and Biochemistry, 56(2), 324-325. doi:10.1271/bbb.56.324

Dávalos, A., Bartolomé, B., and Gómez-Cordovés, C. (2005). Antioxidant properties of commercial grape juices and vinegars. Food Chemistry, 93(2), 325-330. doi:10.1016/j.foodchem.2004.09.030.

Dehpour, A. A., Ebrahimzadeh, M. A., Fazel, N. S., and Mohammad, N. S. (2009). Antioxidant Activity of Methanol Extract of Ferula Assafoetida and Its Essential Oil Composition. Grasas Aceites, 60(4), 405-412.

Direktorat Jenderal Perkebunan. (2020). Produksi Kopi Menurut Provinsi di Indonesia, 20152019. $1 \mathrm{hlm}$

Farah, A., and Donangelo, C. M. (2006). Phenolic compounds in coffee. Brazilian Journal of Plant Physiology, 18(1), 23-36. doi:10.1590/s167704202006000100003.

Farah, A., and dePaula Lima, J. (2019). Consumption of Chlorogenic Acids through Coffee and Health Implications. Beverages, 5(1), 1-29. doi 10.3390/beverages5010011.
Hall, S., Desbrow, B., Anoopkumar-Dukie, S., Davey, A. K., Arora, D., McDermott, C., Schubert, M.M., Perkins, A.V., Kiefel, M.J., Grant, G. D. (2015). A review of the bioactivity of coffee, caffeine and key coffee constituents on inflammatory responses linked to depression. Food Research International, 76, 626-636. doi:10.1016/j.foodres.2015.07.027.

Hounsome, N., Hounsome, B., Tomos, D., and Edwards-Jones, G. (2008). Plant metabolites and nutritional quality of vegetables. Journal of Food Science, 73(4), R48-R65. doi: 10.1111/j.1750-3841.2008.00716.x.

Kebede M, Admassu S. (2019). Application of antioxidants in food processing industry: Options to improve the extraction yields and market value of natural products. Adv Food Technol Nutr Sci Open J., 5(2): 38-49. doi: 10.17140/AFTNSOJ-5-155.

Mulato, S., Widyotomo S., dan Lestari, H. (2001). Pelarutan Kafein Biji Kopi Robusta dengan Kolom Tetap Menggunakan Pelarut Air. Pelita Perkebunan, 17(2), 97-109.

Mursu, J., Voutilainen, S., Nurmi, T., Alfthan, G., Virtanen, J. K., Rissanen, T. H., Happonen, P.,Nyyssonen, K., Kaikkonen, J., Salonen, R., and Salonen, J. T. (2005). The effects of coffee consumption on lipid peroxidation and plasma total homocysteine concentrations: a clinical trial. Free Radical Biology and Medicine, 38(4), 527-534. doi:10.1016/j.freeradbiomed.2004.11.025.

Montavon, P., Mauron, A.-F., and Duruz, E. (2003). Changes in Green Coffee Protein Profiles during Roasting. Journal of Agricultural and Food Chemistry, 51(8), 2335-2343. doi:10.1021/jf020832b.

Molyneux, P. (2004). The use of stable free radical diphenylpicrylhydrazyl (DPPH) for estimating antioxidant activity. Songklanakarin J. Sci. Technol., 2 (26), 211-219.

Nabavi, S.F.,Tejada, S., Setzer, W.N.,Gortzi, O., Sureda, A., Braidy, N., Daglia, M., Manayi, A., and Nabavi, S.M. (2017). Chlorogenic Acid and Mental Diseases: From Chemistry to Medicine. Current Neuropharmacology, 15(4), 471-479. doi:10.2174/1570159X14666160325120625.

Nakatani, N., Kayano, S., Kikuzaki, H., Sumino, K., Katagiri, K., and Mitani, T. (2000). Identification, Quantitative Determination, and Antioxidative Activities of Chlorogenic Acid Isomers in Prune (Prunus domestica L.). Journal of Agricultural and Food Chemistry, 48(11), 5512-5516. doi:10.1021/jf000422s

Nenadis, N., Zhang, H.-Y., \& Tsimidou, M. Z. (2003). Structure-Antioxidant Activity Relationship of Ferulic Acid Derivatives: Effect of Carbon Side Chain Characteristic Groups. Journal of Agricultural and Food Chemistry, 51(7), 1874-1879. doi:10.1021/jf0261452 
Ozarowski, M., Pietrowiak, A., Gryszczynska, A., De A. Chaves, D.S., Krajewska-Patan, A., Wielgus, K., Seremak-Mrozikiewicz, A. (2019). Comparison of in vitro antioxidative activities of crude methanolic extracts of three species of Passiflora from greenhouse using DPPH, ABTS, and FRAP methods. Sciendo Herba Polonica, 65 (3), 10-21. doi: 10.2478/hepo-2019-0014.

Pathak, L., Agrawal, Y., and Dhir, A. (2013). Natural polyphenols in the management of major depression. Expert Opinion on Investigational Drugs, 22(7), 863-880. doi:10.1517/13543784.2013.794783

Prakash, A., Rigelhof, F., and Miller, E. (2001). Antioxidant Activity: Medallion Laboratories. Analytical Progress, 19(2), 1-4.

Rice-Evans, C.A., Miller, N.J., and Paganga, G. (1996). Structure antioxidant activity relationship of flavonoids and phenolic acids. Free Radic. Biol. $\quad$ Med., 20(7), 933-956. doi:10.1016/0891-5849(95)02227-9.

Rija'i, H.R., Fakhrudin, N., and Wahyuono, S. (2019). Isolation and identification of DPPH radical (2,2-diphenyl-1-pikrylhidrazyl) scavenging active compound in ethyl acetat fraction of Piper acre Blume. Trad. Med. J., 24 (3), 204209. ISSN-e: 2406-9086.

Scalbert, A., and Williamson, G. (2000). Dietary intake and bioavailability of polyphenols. Journal of Nutrition, 130, 2073S-2085S.

Shahidi, F., and Wanasundara, P.K.J.(1992). Phenolic antioxidant. Crit. Rev. Food Sci. Nutr., 32, $67-$ 103. doi: 10.1080/10408399209527581.

Triyanti, D.R. (2016). Outlook Kopi. Pusat Data dan Sistem Informasi Pertanian SekjenKementerian Pertanian, 93 hal ISSN: 19071507.

Venugopal, R and Liu, R.H. (2012). Phytochemical in diets for breast cancer prevention: The importance of resveratrol and ursolic acid. Food Science and Human Wellness, 1(1), 113. doi: 10.1016/j.fshw.2012.12.001

Wikipedia. (2018, 27 Agustus). Quinic acid. Available $27 \quad$ Agustus 2018 from https://en.wikipedia.org/wiki/Quinic acid.

Willett, W. (1994). Diet and health: What should we eat? Science, 264 (5158), 532-537. doi: 10.1126/science.8160011.

Xu, J.G., Hu, Q.P., and Liu, Y. (2012). Antioxidant and DNA-protective activities of chlorogenic acid isomers. J. Agric. Food Chem., 60(46), 11625-11630. doi: 10.1021/jf303771s. 